International Journal of Agriculture, Environment and Bioresearch

Vol. 5, No. 06; 2020

ISSN: $2456-8643$

\title{
PHYSICAL PROPERTIES OF SOME DIHAPLOID VARIETIES AND LINES FROM THE TOBACCO TYPE PRILEP
}

\author{
Nataša Zdraveska Gordana Miceska, Miroslav Dimitrieski and Biljana Gveroska \\ University St. KlimentOhridski, Bitola, Scientific Tobacco Institute, Prilep \\ https://doi.org/10.35410/IJAEB.2020.5582
}

\begin{abstract}
Oriental tobaccos in the Republic of Macedonia are selected according to classical methods, which is quite a long process. Today, one of the most commonly used biotechnological methods in plants is the doubled haploid method, whose main purpose is to shorten selection processes in field conditions, while obtaining homozygous lines in the first generation. Tobacco is an ideal plant for the production of haploid plants, tobacco crops produce an explosion of haploids that are being used today in the process of tobacco hybridization. Dihaploidization was performed by direct and rogenesis of haploid tobacco plants obtained in the laboratory in vitro at the Scientific Tobacco Institute - Prilep, using the tissue culture method. Four dihaploid lines of tobacco were included in the research, as follows: P 146-7 / 1 DH, Jk.1. 301/23DH, Hybrid 301 / n DH, Jk.1.75$301 \mathrm{DH}$ and their analogues (P 146-7 / 1 Ø, Hybrid 301/23 Ø, Hybrid 301 / n Øand Jk.1.75-301 $\varnothing$ ).Materiality as an expression of the quality of the leaf tissue varies from $25.96 \mathrm{~g} / \mathrm{m}^{2}$ (Hybrid $301 / \mathrm{n} \mathrm{DH}$ ) to $36.91 \mathrm{~g} / \mathrm{m}^{2}$ (Jk.1. 301/23 Ø). The leaf thickness of the tested dihaploid lines and tobacco varieties is within the range from $76.00 \mu \mathrm{m}$ (Hybrid $301 / \mathrm{n} \mathrm{DH}$ ) to $134.50 \mu \mathrm{m}$ (Hybrid. $301 / 23 \varnothing)$.
\end{abstract}

Keywords: Tobacco, Dihaplod lines, Hybridization, Materiality.

\section{INTRODUCTION}

Of the total arable land in Macedonia, tobacco takes up 3.4\%, and in the total area with industrial crops, it takes up $81.1 \%$ of the total area.

Three tobacoo types with dominant commercial characteristics are produced in the world: Virginia, Burley and Oriental tobacco types, which account for $90 \%$ of the world production and are intended for the production of cigarettes.

In the Republic of Macedonia, tobacco has been grown continuously for almost four centuries. Oriental, semi-oriental and large-leaf tobacco types have been grown in this long period. In the economy of the Republic of Macedonia, tobacco has an important position due to the total value of the production itself and its economic-sociological importance. Today the production of oriental tobacco in the Republic of Macedonia is organized on 15,881 ha (2009-2018), with an average production of 24,716 tons of tobacco. Oriental tobacco in the Republic of Macedonia is selected according to classical methods, which is a very long process. Since the ontogenetic development of tobacco depends primarily on its biological characteristics, and heredity as a characteristic is one of the fundamental manifestations of plant organisms, which is differently 
Vol. 5, No. 06; 2020

ISSN: $2456-8643$

manifested depending on environmental conditions, recently a need has emerged to become more familiar with these processes.

Today, one of the most commonly used biotechnological methods in plants is the doubled haploid method, whose main purpose is to shorten the selection processes in field conditions, while obtaining homozygous lines in the first generations, and based on the various combinations that occur at the level of gametes, consolidation of lines and creation of new varieties (Morison, Evans 1988).

Tobacco is an ideal plant for obtaining haploid plants, tobacco crops produce an explosion of haploids that are used today in the process of obtaining dihaploid plants, which are then used in the process of tobacco hybridization.

The double haploid method is one of the most implemented biotechnical methods today. Seitz (Burchet, 2004) said: "If hybrid induction was the greatest breakthrough in the selection, and the use of biological laboratories was the second greatest breakthrough, then doubled haploid technology would be the third."

The main goal of this method is to shorten the process of obtaining new varieties in field conditions where the processes of self-pollination and selection continue until uniformity of the varieties is achieved and until 100\% of them become homozygous. It takes 9 to 11 years to standardize some varieties or to obtain new varieties (Patrascu, Ioan, 1984).

Gornik (1973), in his research on the materiality of tobacco leaves, came to the conclusion that materiality changes and has a variable magnitude within certain limits and depends on the type, variety, insertion, agro-environmental conditions, technical maturity of the leaf and harvesting processes.

According to Tomič, Demin (1977), the thickness of the tobacco leaf varies from 50 to $150 \mu \mathrm{m}$. The authors point out that the leaf is thin when the average thickness of the leaf tissue is up to $70 \mu \mathrm{m}$, medium thickness is when the leaf tissue has $70-100 \mu \mathrm{m}$ and the thick leaf tissue is the one with more than $100 \mu \mathrm{m}$ (micrometers).

There are some controversial issues regarding the advantages and disadvantages of haploid methods, i.e. the method of induced androgenesis in obtaining dihaploid homozygous plant lines. In order to overcome or clarify some of these doubts, our aim in this paper is to examine the quality properties of some tobacco diploid lines in comparison with their analogues, as well as to confirm the application of induced androgenesis, depending on the objectives of the selection in obtaining homozygous dihaploid tobacco lines.

We hope that the examinations and obtained results in this paper will be the basis inselection processes and that biochemical methods (tissue culture and androgenesis) will be successfully applied in obtaining new superior homozygous lines and tobacco varieties.

\section{MATERIAL AND METHOD}

The examinations were performed in the experimental field at the Scientific Tobacco Institute Prilep in 2014. The examinations included four dihaploid tobacco lines P 146-7/1 DH, Jk.l. 301/23 DH, Hybrid 301/n DH, Jk.1.75-301 DH and their analogues (P 146-7/1 Ø, Jk.l, 301/23 Ø, Hybrid 301/n, Jk.1. 75-301 Ø), Figures no. 1-7.

Dihaploidization was performed by direct androgenesis of haploid tobacco plants obtained in the laboratory in vitro at the Scientific Tobacco Institute - Prilep, using the method of tissue culture 
(meristems, leaf sections with a size of $0.5 \mathrm{~cm}$ ) on a nutrient medium (Murashige\&Skoog, 1962), modified for direct organogenesis and optimized with the following chemical substances: casein - hydrolyzate - $1 \mathrm{mg} / \mathrm{l}$; L - glutamine - $250 \mathrm{mg} / \mathrm{l}$; glycine - $200 \mathrm{mg} / \mathrm{l}$; IAA - $0.2 \mathrm{mg} / \mathrm{l}$; BAP - $0.5 \mathrm{mg} / \mathrm{l}$; adenine - $20 \mathrm{mg} / \mathrm{l}$; kinetine $-3 \mathrm{mg} / \mathrm{l}$ and myoinosite $-100 \mathrm{mg} / \mathrm{l}$. The first dihaploid plants were grown in the biological laboratory in pots with a soil : perlite ratio (3:1) until seed material was obtained from them.

The seedlings from the examined tobacco lines and varieties were produced in the usual manner, in the nursery of the Scientific Tobacco Institute -Prilep, wherebyall necessary agrotechnical and protective measures were applied during the cultivation of the seedlings in order to obtain healthy and normally developed seedlings. The trials were performed according to the method of random block systemin 4 repetitions. The transplanting was carried out at a distance of $40 \mathrm{~cm}$ between rows, $15 \mathrm{~cm}$ in a row. Tobacco harvesting was performed manually, in a stage of technical maturity of the leaves. During the vegetation of the tobacco in the fields, the usual agro-technical and protective measures were applied for protection of tobacco against diseases and pests. The qualitative assessment of the dried tobacco was performed according to the applicable Rulebook for single criteria for tobacco purchase.

The analyses of the physical properties were performed in the accredited laboratory of the Scientific Tobacco Institute, in accordance with the standard MKS EN ISO/IEC 17025: 2006, pursuant to recognized standard methods. The following physical properties were examined: materiality, thickness, and content of the main (mid) rib of the leaves.

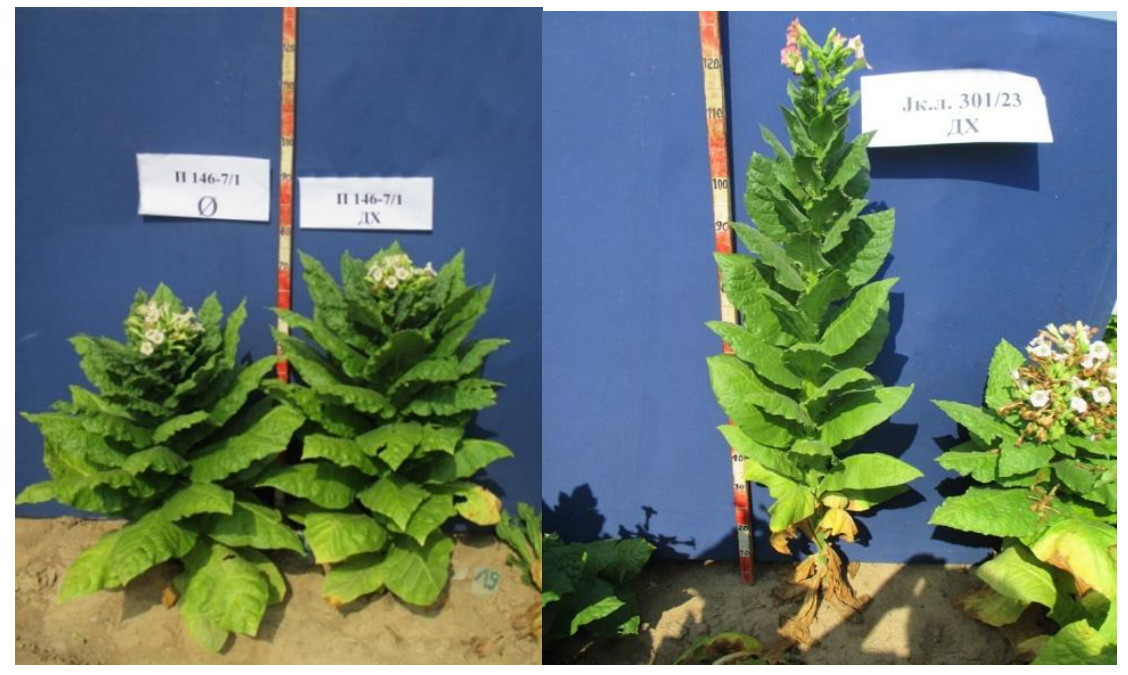

Figure 1.P 146-7/1 ØandP 146-7/1 DHFigure 2.Jk.1. 301/23 Ø 
International Journal of Agriculture, Environment and Bioresearch

Vol. 5, No. 06; 2020

ISSN: $2456-8643$
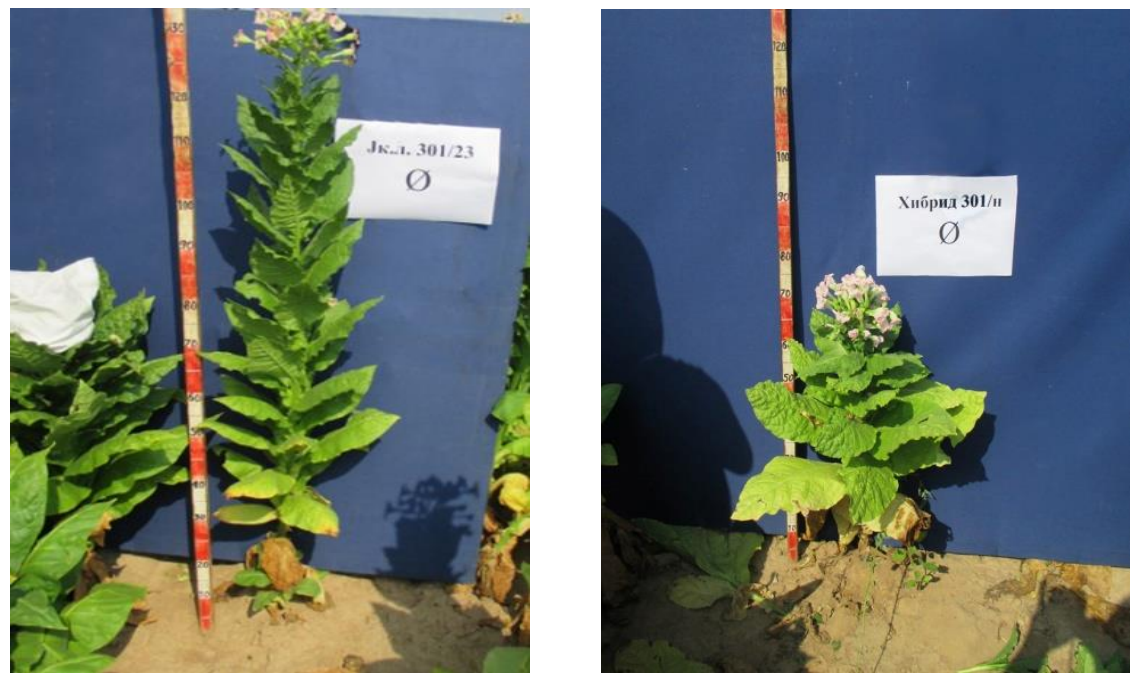

Figure 3.Jk.1 301/23DH

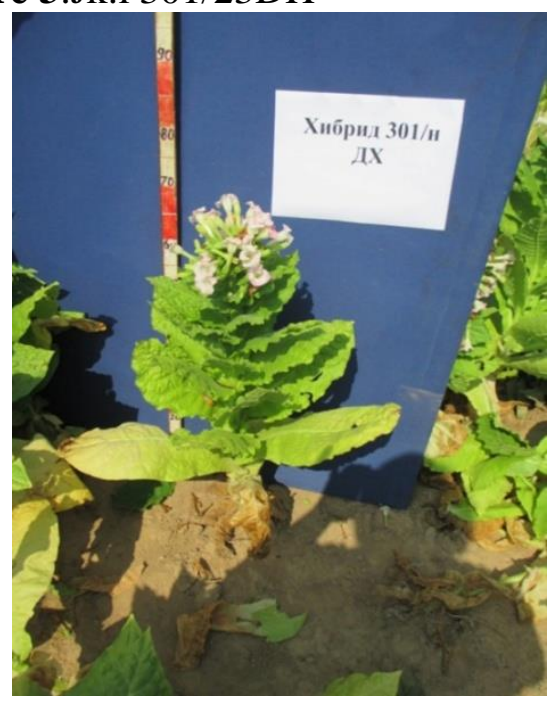

Figure 5.Hybrid 301/n DH
Figure 4.Hybrid 301/n Ø

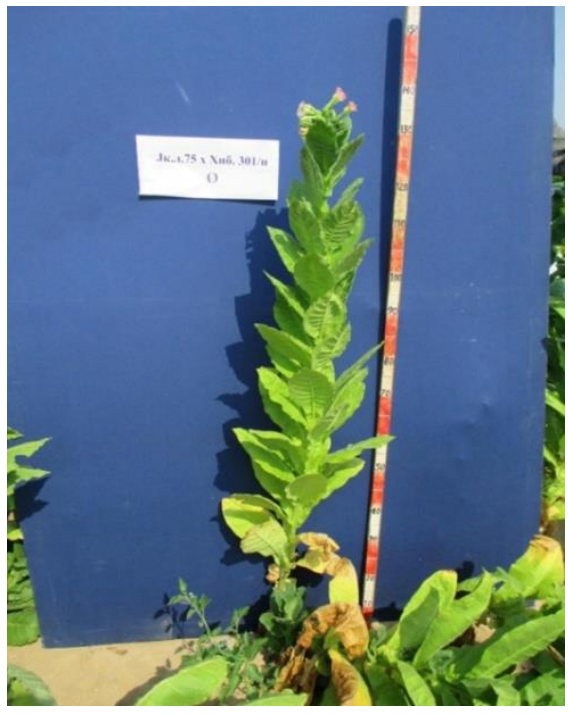

Figure 6.Jk.1.75-301 Ø 


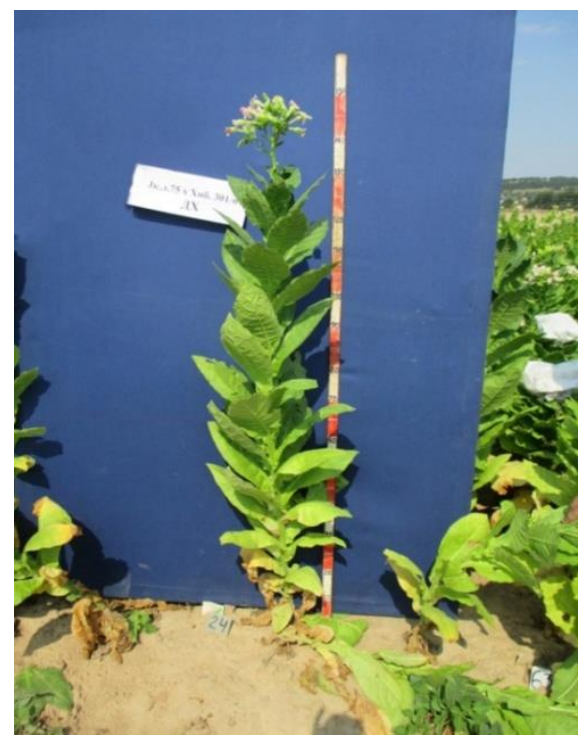

Figure 7.Jk.1.75-301 DH

\section{AGRO-CHEMICAL CONDITIONS}

One of the important factors for the development, the yield and especially for the quality of the tobacco plant (chemical and physical properties) are the climatic conditions during the vegetation period of the tobacco. To that end, during our examination, the following meteorological data were analyzed: average decadal and monthly air temperature, decadal and monthly amounts of precipitation and average decadal and monthly relative humidity.

The data presented in Table 1 show that the average monthly air temperature in 2014 is $18.3^{\circ} \mathrm{C}$.

The average monthly minimum air temperature is $11.3^{\circ} \mathrm{C}$, and the average monthly maximum temperature is $27.0^{\circ} \mathrm{C}$.

Table 1.Average decadal and monthly air temperature for the period May - September 2014

\begin{tabular}{|l|l|l|l|l|l|l|l|}
\hline \multirow{2}{*}{ Meteorological factors } & \multirow{2}{*}{ Decade } & \multicolumn{4}{|l|}{ Months } & \multirow{2}{*}{$\mathbf{\Sigma} / \mathbf{X}^{\mathbf{0}} \mathbf{C}$} \\
\cline { 3 - 9 } & & May & June & July & August & September & \\
\hline \multirow{2}{*}{$\begin{array}{l}\text { Average decadal air } \\
\text { temperature }{ }^{\circ} \mathrm{C}\end{array}$} & I & 12,4 & 16,8 & 21,5 & 20,6 & 17,4 & \\
\cline { 2 - 9 } & II & 13,6 & 18,7 & 19,8 & 22,5 & 17,2 & \\
\cline { 2 - 9 } & III & 16,3 & 20,5 & 21,3 & 22,0 & 13,6 & \\
\hline $\begin{array}{l}\text { Average monthly air } \\
\text { temperature }{ }^{\circ} \mathrm{C}\end{array}$ & & 14,1 & 18,7 & 20,9 & 21,7 & 16,0 & 18,3 \\
\hline
\end{tabular}




\begin{tabular}{|c|c|c|c|c|c|c|c|}
\hline $\begin{array}{lr}\text { Average } & \text { monthly } \\
\text { maximum } & \text { air } \\
\text { temperature }{ }^{\circ} \mathrm{C} & \\
\end{array}$ & & 21,8 & 27,7 & 30,2 & 31,6 & 23,9 & 27,0 \\
\hline $\begin{array}{l}\text { Average monthly } \\
\text { minimum temperature }{ }^{\circ} \mathrm{C}\end{array}$ & & 7,7 & 11,4 & 12,9 & 13,6 & 11,1 & 11,3 \\
\hline \multicolumn{7}{|l|}{ Meteorological factors } & $\begin{array}{l}\Sigma / \mathbf{X} \\
\mathbf{l} \mathbf{m}^{2}\end{array}$ \\
\hline \multirow{3}{*}{ Precipitation $\mathrm{mm}$} & I & 15,0 & 1,0 & 0,0 & 16,0 & 76,0 & \\
\hline & II & 8,0 & 10,0 & 43,0 & 0,0 & 16,0 & \\
\hline & III & 14,0 & 0,0 & 8,0 & 1,0 & 15,0 & \\
\hline Total precipitation $\mathrm{mm}$ & & 37,0 & 11,0 & 51,0 & 17,0 & 107,0 & 223,0 \\
\hline
\end{tabular}

According to Uzunoski (1985), the optimal air temperature for normal growth and development of tobacco plants is within the range from 20 to $30^{\circ} \mathrm{C}$, and the maximum temperature is from 40 to $50^{\circ} \mathrm{C}$.

According to Atanasov (1962), the limit values of lack of temperature are below $18^{\circ} \mathrm{C}$, and the limit values of excessive temperature are above $30^{\circ} \mathrm{C}$.

From the average data in Table 1 it can be concluded that the temperatures during the vegetation are within the allowed temperature limits that ensure normal growth and development of tobacco.

According to the amount of precipitation (Table 1), in 2014 during the vegetation, there was a total of $223.0 \mathrm{~mm}$ of rainfall. According to the literature, this amount corresponds to the needs of the small-leaf aromatic tobaccos, but still, the distribution of precipitation by decades and months is quite irregular.

The soil at the experimental field within the Scientific Tobacco Institute in Prilep, where the trials were conducted in the year of the examination, is of deluvial (colluvial) type (Table 2). This type of soil is most present in the Prilep production area, where tobacco is grown mainly as a monoculture.

\section{RESULTS AND DISCUSSION}

\section{Physical properties}

The physical properties of tobacco leaves are a basic indicator that in practice allows assessment of the tobacco quality, i.e. they are a reflection of their structure and chemical composition, and are closely related to the gustatory properties of tobacco. The study of the dependence of tobacco's quality on its physical properties is of special importance, because the physical properties primarily determine the so-called technological-commercial quality of the tobacco leaf (Uzunoski 1985). 
Starting from the fact that these properties are of great importance in the industrial processing of tobacco, in our research, we decided to analyze the following important physical properties: materiality of the leaves, thickness of the leaves and presence of the main (mid) rib.

\section{Materiality of the leaves}

Materiality is the dry matter content contained in a unit leaf area, regardless of its importance to the tobacco quality.

This property as a physical indicator is of special importance in the fabrication of tobacco, and, in fact, it is a total expression of the internal structure of the leaf of all its properties (Uzunoski 1985). Tobacco materiality can positively or negatively affect quality.

From the data in the examined tobaccos in (Table 3, Graph 1) one can observe that the materiality is within the range from $25.96 \mathrm{~g} / \mathrm{m}^{2}$ to $41.76 \mathrm{gr} / \mathrm{m}^{2}$. The dihaploid line Hybrid $301 / \mathrm{n}$ DH $\left(25.96 \mathrm{~g} / \mathrm{m}^{2}\right)$ has the lowest materiality of the middle leaves, and the line Jk.l. $301 / 23 \varnothing$ $\left(36.91 \mathrm{~g} / \mathrm{m}^{2}\right)$ has the highest materiality. The dihaploid line P $146-7 / 1 \mathrm{DH}\left(26.85 \mathrm{~g} / \mathrm{m}^{2}\right)$ is characterized by the lowest materiality of the sub-leaves, and the highest materiality is observed in Jk.1.75-301 DH, of $41.76 \mathrm{~g} / \mathrm{m}^{2}$.

Gornik (1973)indicates that materiality is a variable measurement within certain limits and depends on the type, variety, insertion, agro-ecological conditions, technical maturity of the leaf and harvesting processes.

Table3.Materiality of the leaves, $\left(\mathrm{g} / \mathrm{m}^{2}\right)$

\begin{tabular}{|l|l|l|}
\hline \multirow{2}{*}{ Varieties/Lines } & Insertion & Sub-leaves \\
\cline { 2 - 3 } & True middle leaf & 39,55 \\
\hline P 146-7/1 Ø & 33,62 & 26,85 \\
\hline P 146-7/1 DH & 33,07 & 32,48 \\
\hline Jk.1. 301/23 Ø & 36,91 & 38,46 \\
\hline Jk.1. 301/23 DH & 32,67 & 28,51 \\
\hline Hybrid 301/n Ø & 28,17 & 35,62 \\
\hline Hybrid 301/nDH & 25,96 & 37,81 \\
\hline Jk.1.75-301 Ø & 33,62 & 41,76 \\
\hline Jk.1.75-301 DH & 29,98 & \\
\hline
\end{tabular}

Nuneski (1986), in his studies comes to the conclusion that the filling ability of tobacco is inversely proportional to the absolute weight, i.e. when the absolute weight is higher, the filling ability is lower.

Materiality is a typical or varietal characteristic and depends on several factors. 
According to the studies byNuneski (1986), the three-year average materiality of the type Prilepin the region of Prilep is $57.7 \mathrm{~g} / \mathrm{m}^{2}$.

Dimitrieski (1990) points out that the average materiality of the sub-leavesin five examined varieties of the type Prilepvaried from $69.49 \mathrm{~g} / \mathrm{m}^{2}$ to $93.12 \mathrm{~g} / \mathrm{m}^{2}$.

The rains that fell in the second and third decade of July $(51 \mathrm{~mm})$ have a particularly negative influence, in the first decade of August $(16 \mathrm{~mm})$, as well as in the first decade of September, in the period when these insertions were formed.

Our values of the examined varieties/lines are slightly lower than the literature data considering that in the 2014 yield, the distribution of precipitation by decades is irregular during the vegetation period of tobacco when the total precipitation is $223 \mathrm{~mm} / \mathrm{m}^{2}$.

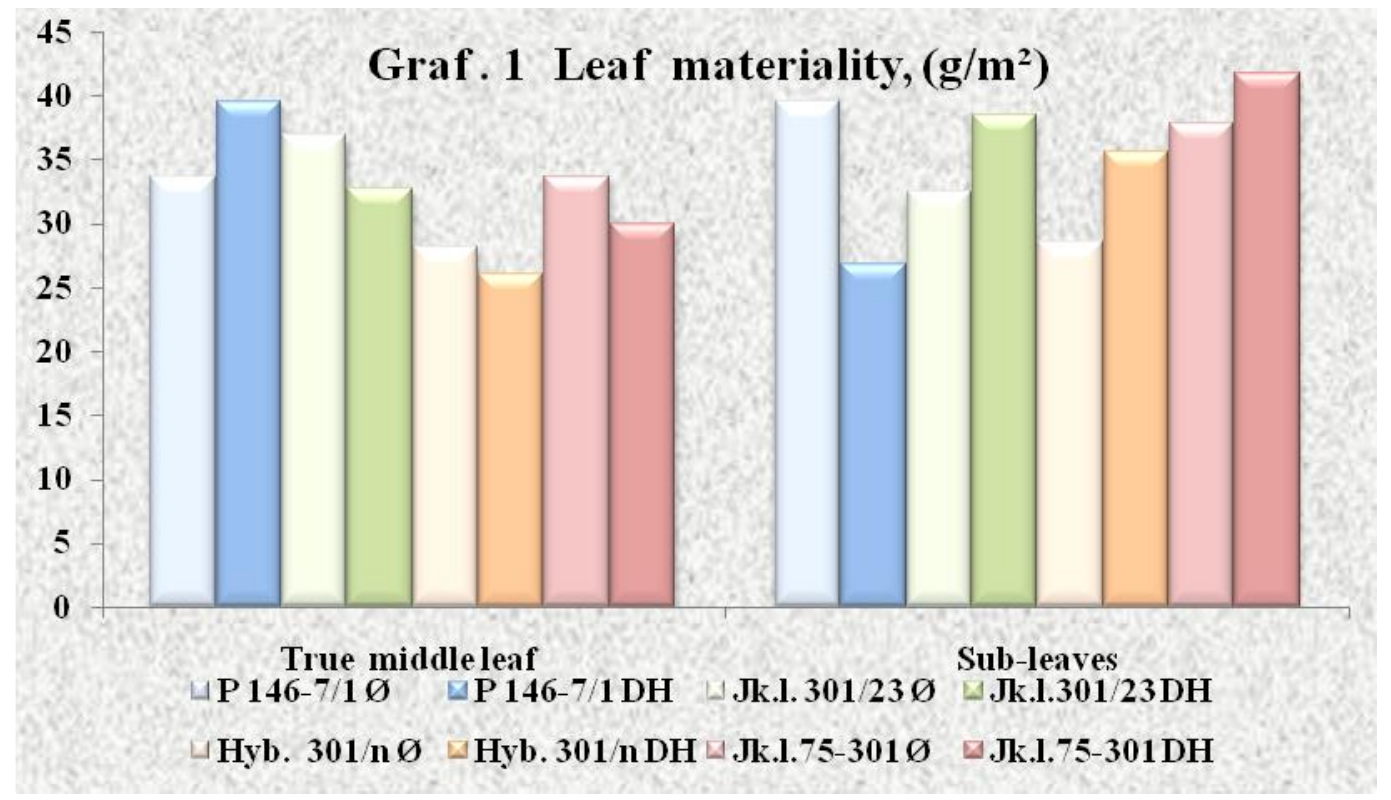

\section{Leaf thickness}

Leaf thickness is one of the most important physical properties according to which the quality of the tobacco raw material is determined and it is an expression of the anatomical structure of the leaf which is a result of the size of the parenchymal cells, the intercellular spaces and the cuticle.

The leaf thickness is a typical and varietal characteristic, but it also widely variesdepending on the agro-ecological factors, the insertion, the degree of maturity and the course and the character of the harvesting processes (Atanasov, 1962 and Boceski, 1984).

According to Uzunoski (1985), the leaf thickness is inversely proportional to the tobacco quality. The thicker the tobacco leaf, the lower the quality and vice versa, if the thinness of the leaf is not the result of malnutrition.

According to Tomič, Demin (1977), the thickness of the tobacco leaf varies from 50 to $150 \mu \mathrm{m}$. The authors point out that the leaf is thin when the average thickness of the leaf is up to $70 \mu \mathrm{m}$; medium thickness is when the leaf tissue is $70-100 \mu \mathrm{m}$ and thick leaf tissue is the one that exceeds $100 \mu \mathrm{m}$ (micrometers). 
Bogdancheski et al. (1988), examining the technological properties of several varieties of the type Prilepin the region of Delchevo, concluded that the average thickness of the sub-leaves is from 78 to $95 \mu \mathrm{m}$.

The results of our examinations regarding the leaf tissue thickness are presented in Table 4. Namely, the thickness of the true middle leaf is within the range from $76.00 \mu \mathrm{m}$ in Hybrid $301 / \mathrm{n}$ DH to $111.50 \mu \mathrm{m}$ in Jk.1.301/23 Ø. The lowest thickness of the sub-leaves of 100.50 is observed in Hybrid 301/n Ø, and the highest inJk1.1. 301/23 Ø, of $134.50 \mu \mathrm{m}$. If we analyze them by insertions, we come to the conclusion that the thickness of the leaves increases from the middle belt to the upper belt.

The values of the thickness of the leaves from our examinations do not deviate from the cited literature data, although in the examined leaves from the dihaploid lines we have slightly lower values than in their analogues, still, we can conclude that according to this physical indicator, the tobacco raw material from the examined varieties/lines corresponds to the indicated commodity type of tobacco.

Table4.Thickness of the leaves, $(\mu \mathrm{m})$

\begin{tabular}{|l|l|l|}
\hline \multirow{2}{*}{ Varieties/Lines } & Insertion & \multicolumn{2}{l|}{} \\
\cline { 2 - 3 } & True middle leaf & Sub-leaves \\
\hline P 146-7/1 Ø & 88,50 & 117,50 \\
\hline P 146-7/1 DH & 93,00 & 121,00 \\
\hline Jk.1. 301/23 Ø & 111,50 & 134,50 \\
\hline Jk.1. 301/23 DH & 93,50 & 127,50 \\
\hline Hybrid 301/n Ø & 92,00 & 100,50 \\
\hline Hybrid 301/nDH & 76,00 & 101,50 \\
\hline Jk.1.75-301 Ø & 99,50 & 111,50 \\
\hline Jk.1.75-301 DH & 86,00 & 120,00 \\
\hline
\end{tabular}

\section{Content of the main (mid) rib}

Oriental tobacco types are characterized by fine and delicate leaf tissue with a poorly expressed nervature. The leaf nervature is an important indicator of the tobacco quality. It consists of a main conductive vessel (main rib) and secondary conductive vessels (secondary ribs). The higher percentage of participation in the main rib impairs the external appearance of the leaves and as an integral part of the cut tobacco it affects the homogeneity of cigarettes, thereby deteriorating their physical and gustatory properties.

The presence of the main rib in the leaf depends on the tobacco type and variety, the climatic conditions, the insertion and the maturity of the tobacco. 
Uzunoski (1985) points out that the high percentage of ribs (nervature) always testifies to the lower quality of tobacco, because the chemical composition of the main rib differs from that of the parenchyma.

As the materiality increases, the percentage of the main rib decreases.

The leaf nervature is a varietal trait, but to a greater extent depends on growing conditions. The main nerve contains less nicotine, soluble sugars, proteins, resins and essential oils, and more cellulose, lignin, mineralsubstances, especially chlorine, calcium and acids, of which especially oxalic acid, which gives it a bitter taste when smoked.

Table5.Content of the main rib, $(\%)$

\begin{tabular}{|l|l|l|}
\hline \multirow{2}{*}{ Varieties/Lines } & Insertion \\
\cline { 2 - 3 } & True middle leaf & Sub-leaves \\
\hline P 146-7/1 Ø & 16,18 & 12,98 \\
\hline P 146-7/1 DH & 17,59 & 12,96 \\
\hline Jk.1. 301/23 Ø & 13,15 & 13,49 \\
\hline Jk.1. 301/23 DH & 16,45 & 13,56 \\
\hline Hybrid 301/n Ø & 24,43 & 18,43 \\
\hline Hybrid 301/nDH & 24,72 & 14,30 \\
\hline Jk.1.75-301 Ø & 17,28 & 14,40 \\
\hline Jk.1.75-301 DH & 20,20 & 13,87 \\
\hline
\end{tabular}

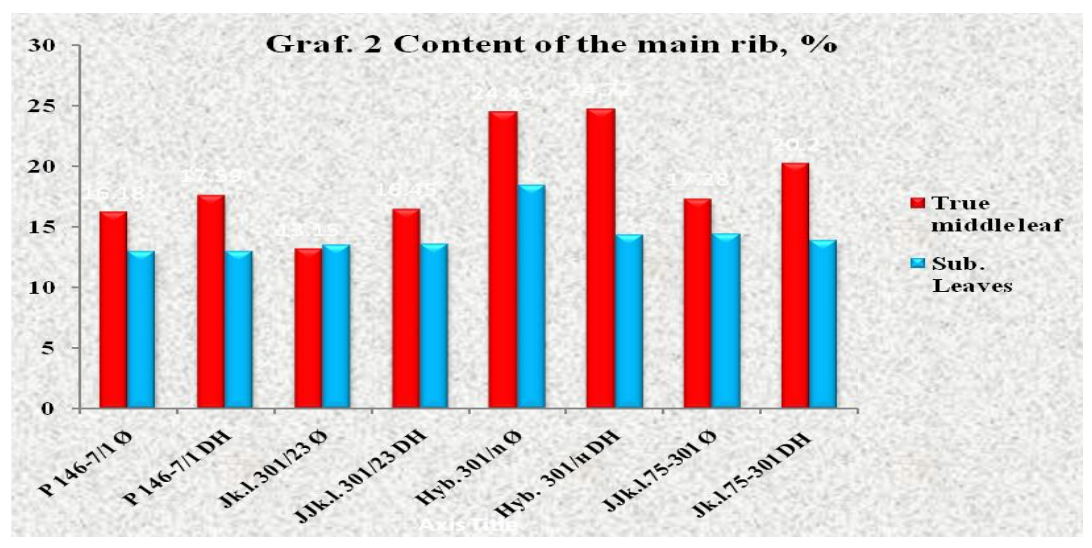

From the data regarding the percentage share of the main rib in the total leaf weight of the examined dihaploid lines and their analogues (Table 5, Graph 2), it can be seen that the 
percentage of the main rib is within the range from $12.96 \%$ in P 146-7/1 DHto $24.72 \%$ in Hybrid $301 / \mathrm{n} \mathrm{DH}$. The percentage of representation of the main rib in the true middle leaves is lowest in Jk.1. $301 / 23 \varnothing$ and amounts to $13.15 \%$, and it is highest, 24.72\%, in Hybrid 301/n DH.

The lowest percentage of the main rib of the sub-leaves is observed in the dihaploid line $\mathrm{P}$ $146-7 / 1 \mathrm{DH}, 12.96 \%$, and the highest percentage of $18.43 \%$ is observed in Hybrid 301/n Ø. If we analyze them by insertions, one can come to the conclusion that the percentage of the main rib decreases from the middle to the upper belt. However, if we compare the values for the percentage of the main rib in the dihaploid lines compared to their analogues in both examined insertions, all dihaploid lines have a lower percentage of the main rib in the sub-leaves which ranges from $12.96 \%$ to $13.56 \%$.

From the results in our examinations, it can be concluded that the content of the main rib in the dihaploid lines and their analogues is small, which is actually a good indicator and is of special interest for cigarette fabrication.

\section{CONCLUSIONS}

Considering the literature data, as well as the data from our research, we can come to the following conclusions:

- Materiality as an expression of the quality of the leaf tissue of the middle leaves ranges from $25.96 \mathrm{~g} / \mathrm{m}^{2}$ in the dihaploid line Hybrid 301/n DH to $36.91 \mathrm{~g} / \mathrm{m}^{2}$ in Jk.1. $301 / 23 \varnothing$, while the lowest materiality of the sub-leaves of $26.85 \mathrm{~g} / \mathrm{m}^{2}$ is present in the dihaploid line $\mathrm{P}$ $146-7 / 1 \mathrm{DH}$, and the highest materiality of the sub-leaves is observed in Jk.1.75-301 DH from of $41.76 \mathrm{gr} / \mathrm{m}^{2}$.

- The leaf thickness of the examined dihaploid lines and tobacco varieties ranges from $76.00 \mu \mathrm{m}$ in Hybrid 301/n DH to $134.50 \mu \mathrm{m}$ in Jk.l. 301/23 Ø. If we analyze them by insertions, we come to the conclusion that the thickness of the leaves increases from the middle to the upper belt.

- The percentage share of the main rib in the total leaf weight of the examined dihaploid lines and their analogues ranges from $12.96 \%$ in P $146-7 / 1$ DH to $24.72 \%$ in Hybrid 301/n $\mathrm{DH}$.

- Modern biotechnical methods for plants (tissue culture and androgenesis) can be successfully applied in the selection programs of oriental tobacco for obtaining uniform offspring.

- Dihaploid lines according to their technological properties can successfully be the starting material for further selection studies in obtaining new varieties of tobacco, which results in shortening the time period for obtaining new varieties, which otherwise requires 510 years according to the classical selection methods.

\section{REFERENCES}

[1] Атанасов Д. 1962.Тютюпроизводство, Пловдив.

[2] Богданчески М., Мицеска Г., Чавкароски Д., Димитриески М. 1988. Резултати од компаративните испитувања на некои ориенталски сорти тутун во реонот на Делчево во 1987 година. Зборник на трудови, 14 Меѓународен симпозиум по тутун, стр. 21-30. 
[3] Deaton W.R., Collins G.B., Nelson M.T., 1986. Vigor and variation ehpressed by anther derived doubled haploids burley tobacco (Nicotianatabaccum). I Comparasion of sexual and doubledhaploidpopulatons.Euphytica.Vol. 35 (1) 33.

[4] Devereux M., Lameri U. 1974. Anther culture haploid plantisogenie line and breeding research in N. tabaccum L.- In: Poliploidy and induced mutations in plant breeding. Atomic Energy Agency, Viena 503,15, 101-107.

[5]Димитриески М., 1990.Биолошки, производни и квалитетни својства на некои нови сорти тутун од ароматичен тип. Магистерска тема, Скопје.

[6]Димитриески М., Аческа Н., Чавкароски Д., Мицеска Г.,1992. Влијаниенаагроеколошкитеусловиврзморфолошките, производните квалитетнитесвојствананекоисортитутунодтипотјака.Тутун/ Tobacco Vol., $\mathrm{N}^{\mathrm{o}}$ 1-6 [7]Dimitrieski M., MiceskaG . 2013.Productional characteristics of some oriental tobacco lines resistant to black shank (phytophtora parasitica var. nicotianae). Tutun/Tobacco, Vol. $63 \mathrm{~N}^{\circ} 7-12$. [8]ЕнчеваЮ.,Стойкова Д., Машева В., 2000.Създаваненаисходенселекционенматеријалчрезиндуциран андрогенезис in vitro.Вишселскостопанскиинститут-Пловдив, Научнитрудове, м, XLV, 2000, стр.107-112. [9]Митрески М. 2012.Компаративни проучувања на поважните производни, технолошки и квалитетни својства кај некои сорти тутун од типот прилеп. Докторска дисертација, Научен институт за тутун-Прилеп.

[10] МицескаГ.,Димитриески М., 2006. Дихаплоиди од антери на ориенталски тутун и нивните морфолошки својства. Тутун/ TobaccoVol. 56 No 5-6, стр.85-91.

[11]Miceska G. 2009. Agronomic characteristics of dihaploid lines of oriental tobacco obtained in vitro.ACS Vol. $74 \mathrm{~N}^{\mathrm{o}} 4$ pp 1-4.

[12]Мицеска Г. 2009. Продукција на хаплоиди кај тутунот in vitro Тутун/Tobacco, Vol.59, № 9-10, 201-206.

[13] Miceska G. 2011. Determination of the level of androgenesis in tobacco .JCEA Vol.12, $\mathrm{N}^{0} 3$ p. 515-518.

[14] Morrison R.A., Evans D.A. 1988. Haploid plants from tissue culture: New plant varieties in a Shortened time frame. Bio/Tehnology 6, 684-690.

[15] Nitsch, J. P. 1969. Experimental androgenesis in Nicotiana.Phytomorphology, (19) 389-404. [16] Nitch, J.P., Nitch, C., 1969.Haploid plants from pollen grains. Science 163, 85-87.[17] Нунески И. 1986. Придонес кон запознавањето на полнечката способност на тутунот во зависност од типот, потеклото, инсерцијата и некои технолошки својства. Докторска дисертација. Земјоделски факултет - Скопје.

[18] Patrascu M., Ioan E.1984. Nouveaux genotypes de tabac, obtenus par manipulation in vitro des microspores. (autors manuscript).

[19]Seitz G. 2004. A dark horse leads the seed industry with a new breeding tecnology. F. J. 14. (Article).

[20]TomičLj., Demin A. 1977.Tehnologijaproizvodnje i poznavanjeduvana, Subotica - Beograd.

[21] Узуноски М. 1977.Поважни технолошки својства на тутунската суровина

од типот отља во зависност од степенот на зрелоста и бојата на лисјата.

( Докторска дисертација Одбранета 1969) Земјоделски ф-тет Скопје

[22].Узуноски М. 1985.Производствонатутун,Стопанскивесник, Скопје.

[23]Šmuk A. 1948.Hemija i tehnologijatabaka.Piščepromizdat - Moskva. 